\title{
Poligami di Minangkabau Pada Masa Kolonial
}

\author{
Vitri Puspita Sari ${ }^{1}$ \\ ${ }^{1}$ Program Studi Ilmu Sejarah, Fakultas Ilmu Budaya, Universitas Andalas, Jl. Universitas Andalas, \\ Limau Manis, Kec. Pauh, Kota Padang, Sumatera Barat 25163, Indonesia \\ unandvitri@gmail.com
}

Received 17 January 2020; Received in revised form 02 February 2020; Accepted 28 February 2020

\begin{abstract}
Abstrak
Di Minangkabau poligami merupakan hal yang sudah biasa terjadi pada masa kolonial. Pada masa itu, laki-laki banyak yang mempunyai istri lebih dari satu orang. Mengingat hal itu, penulisan ini penting dilakukan dengan tujuan untuk melihat apakah memang di Minangkabau praktek poligami sering terjadi. Penulisan ini akan menggunakan metode sejarah dengan melihat sumber-sumber pada masa kolonial. Menurut laporan Kolonial Belanda Indisch Verslag terbitan 1931, di Sumatera Barat terdapat sebanyak 271.901 lakilaki yang sudah menikah secara monogami. Sedangkan laki-laki yang beristri dua terdapat sebanyak 20.127 orang. Laki-laki yang beristri tiga orang sebanyak 2.371 orang, dan lakilaki yang mempunyai istri empat terdapat sebanyak 455 orang. Dari jumlah tersebut, Sumatera Barat yang paling banyak berpoligami di antara kota-kota yang ada di Pulau Sumatera.

Kata kunci: Hindia Belanda, sejarah keluarga, pernikahan.
\end{abstract}

\begin{abstract}
In Minangkabau polygamy was common during the colonial period. At that time, many men who had more than one wife. With the aim of seeing whether indeed in Minangkabau the practice of polygamy often occurs, this writing will use the historical method by looking at sources in the colonial period. According to the 1931 Dutch Colonial Indisch Verslag report, in West Sumatra there were 271.901 men who were merried in a monogamous manner. While there are 20.127 married men. Men with three wives were 2.371 people, and men who had four wives were 455 people. Of these, West Sumatra has the most polygamy among cities in Sumatra.
\end{abstract}

Keywords: Netherlands East Indies, history of the family, marriage.

\section{PENDAHULUAN}

Mulai berkuasanya pemerintah Kolonial

Belanda di Minangkabau pada abad ke-

19, menjadi awal diperkenalkannya

aturan-aturan (hukum) barat dalam

kehidupan masyarakat Minangkabau.

Hukum yang berlaku terdiri dari: hukum

perdata (privaatrecht) yaitu hukum yang mengatur perhubungan antar perseorangan, seperti masalah yang ditimbulkan dalam perkawinan, hukum harta benda dan hukum waris dan hukum publik (publiekrecht) adalah hukum yang mengatur kepentingan umum. Tetapi, pemerintah Kolonial Belanda juga mengakui masyarakat adat kecuali di kota-kota yang telah diadakan susunan pemerintahan yang baru, tidak berdasarkan hukum adat dan kekuasaan adat digantikan oleh kekuasaan pegawai pemerintah. Akan tetapi ketika pemerintah Kolonial Belanda berkuasa di Minangkabau, mereka tidak menghendaki berkembangnya hukum Islam. Oleh karena itu, kebijakan pemerintah Kolonial Belanda abad ke-19 
di Minangkabau cenderung anti-Islam. Pemerintah mencoba meniadakan guru agama yang dinamakan "pimpinan spiritual bebas", dan hadji dari memegang adat dan kantor pemerintah mencoba mencegah pemilihan hadji sebagai penghulu (Putri, 2018).

Belanda berupaya menegakkan hukum Belanda-Minangkabau dengan mengumpulkan hukum-hukum lokal agar hukum yang menurut hukum nagari bisa digunakan untuk keseluruhan wilayah Minangkabau. Salah satu koleksi yang disalin di kampung pelabuhan Air Bangis pada tahun 1850-an, yaitu tidak memberi ampun kepada orang yang dibuktikan bersalah melakukan perzinahan. Undang-undang ini merupakan produk yang dibuat oleh Belanda sesuai dengan harapan mereka (Hadler, 2010).

Di dalam syariat Agama Islam memperbolehkan poligami dengan batasan sampai empat orang istri dan mewajibkan berlaku adil kepada mereka, baik dalam urusan pangan, pakaian, tempat tinggal, serta lainnya yang bersifat kebendaan tanpa membedakan dan istri yang miskin, yang berasal dari keturunan tinggi dengan yang rendah dari golongan bawah. Bila suami khawatir berbuat zhalim dan tidak mampu memenuhi semua hak-hak mereka, maka hendaklah tidak berpoligami. Bila yang sanggup dipenuhinya hanya tiga, maka tidak dianjurkan baginya menikah dengan empat orang. Jika dia hanya mampu memenuhi hak dua orang istri maka tidak dianjurkan baginya untuk menikah sampai empat kali. Begitu juga kalau ia khawatir berbuat dzalim dengan menikahi dua orang perempuan, maka baginya tidak dianjurkan untuk melakukan poligami (Darmawijaya, 2015).

Sebagai agama yang sempurna, Islam selalu menjadi rujukan umatnya untuk memenuhi persoalan-persoalan menyangkut hubungan kemanusiaan yang begitu kompleks dan krusial. Bagi umat Islam secara khusus, persoalanpersoalan itu tentunya selalu beriringan dan berkaitan dengan dasar-dasar kehidupan melalui Al-qur'anul karim maupun contoh-contoh teladan yang telah dilaksanakan oleh baginda Rasulullah Muhammad Saw. Salah satu contoh mengenai persoalan umat yang begitu kompleks dan sering menjadi permasalahan serius ditengah-tengah kehidupan, permasalahan tersebut yakninya poligami (Antuli, 2016)

Di Minangkabau salah satu penyebab terjadinya poligami karena tekanan kaum reformis Islam terhadap adat tidak optimal (umumnya dipedesaan). Kaum reformis Islam menginginkan sistem matrilineal dihapus dan diganti seluruhnya dengan sistem yang sesuai dengan ajaran Islam. Ketidak senangan terhadap Belanda 
HISTORIA: Jurnal Program Studi Pendidikan Sejarah Volume 8 (1) 2020

ISSN 2337-4713 (E-ISSN 2442-8728)

menjadi lahan subur bagi gerakan reformis Islam. Serangan terhadap adat di Minangkabau baru dimulai pada akhir abad ke-19. Sebelumnya pamor penghulu, bukan adat, sudah mulai menurun. Hal tersebut terjadi bukan karena ketidakmampuan mereka menjalankan tugas-tugas yang berkaitan dengan adat, tapi karena dukungan terhadap tanam paksa, kerja paksa rodi, dan pajak yang menyebabkan keresahan. Otoritas penghulu menurun akibat terjadinya pengangkatan orangorang pilihan pemerintah kolonial sebagai penghulu, padahal menurut adat mereka tidak mempunyai legitimasi (Amerady Chatra, 2005).

Pada tahun 1908, setelah resminya dicabut sistem tanam paksa (Cultuurstelsel) karena gagal dan diganti dengan pajak uang, para penghulu yang tadinya berpihak kepada Belanda berubah haluan memimpin pemberontakan bersama para pedagang dan guru-guru tarikat. Tindakan ini dilakukan agar kembalinya kepercayaan masyarakat terhadap penghulu. Namun, pemberontakan tersebut menyebabkan penghulu semakin terpuruk, dipandang tidak sanggup memimpin, karena setiap pemberontakan berakhir dengan kegagalan. Alasan pemberontakan tersebut dilakukan adalah tekanan ekonomi dan ketidak sanggupan masyarakat memenuhi peraturan pemerintah. Tanam paksa yang gagal menyebabkan kemerosotan ekonomi, karena keharusan bekerja di kebunkebun kopi yang menyita tenaga dan waktu, sehingga hilangnya kesempatan masyarakat mengembangkan ekonomi mereka (Amerady Chatra, 2005).

Dengan dihapuskannya sistem tanam paksa dan pemberlakuan sistem pajak uang, laki-laki berusaha sekuat tenaga untuk mendapatkan uang. Sistem ekonomi uang berkembang sangat pesat, sehingga melebarnya jurang status ekonomi laki-laki dengan perempuan. Laki-laki lebih menguasai peredaran uang karena mereka lebih dahulu masuk ke sistem tersebut dengan menjadi pedagang, tukang, buruh dan sebagainya. Sedangkan perempuan masih berada hanya di sektor pertanian dan mulai tidak terlindung oleh harta pusaka. Harta pusaka tidak bertambah karena mamak tidak lagi berusaha ke arah itu, sementara populasi kaum makin meningkat. Mamak lebih mencurahkan perhatian kepada anakanak mereka, terpengaruh oleh gerakan kaum muda dan perubahan pola pemukiman dari rumah gadang ke rumah-rumah berukuran kecil (Amerady Chatra, 2005).

Poligami di Minangkabau dapat terjadi juga karena seorang suami dirumah gadang istrinya sebagai seorang sumando, namun demikian bukanlah berarti laki-laki tersebut hilang kemerdekaannya. la tetap merdeka 
seperti biasa sebelum menikah, dan boleh beristri seorang, dua, tiga dan empat, tanpa dapat dihalangi oleh istrinya. Selain itu, semua anak yang dilahirkan oleh perempuan Minangkabau, menurut adat adalah kepunyaanperempuan tersebut, dan bukan kepunyaan suaminya. Anak tersebut menjadi anggota kampuang dan menurut suku ibunya, anak tersebut menjadi anak buah dari mamak dan penghulu pihak inbunya. Menurut hukum adat tidak ada hubungan hukum antara ayah dan anaknya. Bila ibunya diceraikan oleh ayahnya, anak-anak tinggal dengan ibunya, dibawah penjagaan mamaknya dan tidak boleh dibawa oleh ayahnya (Muhammad Radjab, 1969).

Atas latar belakang di atas, kajian ini akan memfokuskan pada kajian poligami di Minangkabau pada masa Kolonial. Untuk menjelaskan semua permasalahan ada beberapa pertanyaan yang diajukan: Bagaimana poligami di Minangkabau pada masa Kolonial? Bagaimana gerakan perempuan pada masa kolonial agar bebas dari belenggu poligami?. Semua pertanyaan tersebut akan dijawab dalam pembahasan berikutnya.

Studi mengenai poligami di Sumatera Barat telah dilakukan oleh beberapa penulis, akan tetapi kajian yang membahas tentang poligami di Minangkabau pada masa Kolonial masih minim. Maka untuk itulah penulisan ini dirasa perlu dan penting dilakukan. Studi tentang poligami masa kolonial di Sumatera Barat khusus Minangkabau ada dilakukan, namun membahas poligami hanya sebagian saja. Wannofri Samry dalam penulisanya "Gagasan dan Aktiviti Wartawan Wanita Minangkabau Pada Masa Kolonial Belanda. Di dalam penulisannya di jelaskan bahwa poligami di Minangkabau terjadi karena fakta sosial yang menunjukkan bahwa seorang suami di Minangkabau apabila kaya dan berpangkat, biasanya bermental bos. Mereka ingin dilayani, mentalitas semacam ini bertentangan dengan sikap istri yang masih belum dewasa, sebab gadis-gadis yang belasan tahun sudah menikah itu masih ingin dimanja. Impaknya adalah tidak harmonisnya hubungan rumah tangga suami dan istri dan suami denganmudahnya beristri lagi atau menceraikan istrinya.("Gagasan dan aktiviti wartawan wanita Minangkabau pada masa kolonial Belanda," 2012)

Arief Budiman, dalam penulisannya “Analisis Yuridis Terhadap Kawin Batambuah Yang Dilakukan Oleh Masyarakat Adat Minangkabau Agam Sumatera Barat". Dalam tulisannya ini membahas tentang masyarakat Agam yang masih terdapat kawin batambuah. Perkawinan tersebut dibahas yang mana hanya dapat dilakukan secara agama saja, yang mana perkawinan tersebut 
HISTORIA: Jurnal Program Studi Pendidikan Sejarah Volume 8 (1) 2020

ISSN 2337-4713 (E-ISSN 2442-8728)

tentu membawa suatu akibat terhadap anak-anak yang lahir dari kawin batambuah dan istri-istri serta harta perkawinannya (Arief Budiman, 2016).

Tulisan Untung Yuwono yang berjudul "Ketika Perempuan Lantang Menentang Poligami: Sebuah Analisis Wacana Kritis Tentang Wacana Anti Poligami". Dalam tulisannya ini membahas tentang polemik poligami yang timbul-tenggelam, namun selalu menjadi isu yang hangat utuk dibicarakan. Selain itu dalam tulisannya dibahas uga tentang undang-undang tentang poligami (Untung Yuwono, 2008).

Untuk menganalisa penulisan ini menggunakan teori wacana. Wacana ini untuk melihat wacana-wacana apa saja yang ada di media yang berkaitan dengan topik penulisan ini. Wacana merupakan tataran bahasa yang terbesar, tertinggi dan terlengkap. Wacana dikatakan terlengkap karena wacana mencangkup tataran di bawahnya, yakni fonologi, morfologi, sintaksis, semantic, dan ditunjang oleh unsur lainnya, yaitu situasi pemakaian dalam masyarakat (Yoce Aliah Darma, 2009).

\section{METODE}

Penelitian ini menggunakan metode penelitian sejarah yang terdiri atas empat tahap yaitu heuristik, kritik, interpretasi dan historiografi (Clark \&
Gottschalk, 1951). Pada tahap Heuristik dilakukan dengan penelitian kepustakaan. Penelitian kepustakaan saya mengunjungi Perpustakaan Nasional, Perpustakaan Universitas Andalas dan Kantor Arsip Nasional. Penelitian ini bertujuan untuk menggumpulkan sumber primer dan sumber sekunder. Untuk sumber primer penulisan ini menggunakan arsip-arsip dan koran-koran sezaman seperti Indies Verslag, koran pedoman masyarakat, soeara kaoem iboe soematera, Asjraq, soenting melajoe dan sebagainya. Untuk sumber sekunder saya menggunakan buku dan karya-karya yang berkaitan langsung dengan penulisan ini.

Tahap kedua dari penelitian sejarah ini yang dilakukan setelah mengumpulkan sumber adalah kritik terhadap sumber. Tahap ini bertujuan untuk mendapatkan kebenaran dari sumber-sumber yang telah diperoleh dari lapangan, sehingga melahirkan suatu fakta. Kritik ini terdiri dari dua bentuk yaitu kritik intern dan kritik ekstern. Kritik intern bertujuan untuk melihat kredibilitas dari isi sumber tersebut. Kritik ekstern bertujuan untuk melihat atau meneliti kertasnya, tintanya, gaya tulisannya, bahasanya, kalimatnya, ungkapan kata-katanya, huruf dan semua penampilan luarnya.

Tahap ketiga setelah dilakukan kritik adalah interpretasi yang berupa penafsiran-penafsiran yang merujuk 
pada fakta-fakta yang dihasilkan. Pada tahap ini dilanjutkan dengan penafsiran data yang telah dikumpulkan dan dikritik. Dilanjutkan dengan tahap terakhir dari metode penelitian sejarah yaitu penulisan atau historiografi. Pada tahap ini fakta-fakta yang ditemukan dideskripsikan dalam bentuk penulisan yang sistematis.

\section{HASIL DAN PEMBAHASAN}

\section{Poligami di Minangkabau}

Menurut laporan Kolonial Belanda Indisch Verslag terbitan 1931, di Sumatera Barat terdapat sebanyak 271.901 laki-laki yang sudah menikah secara monogami. Sedangkan laki-laki yang beristri dua terdapat sebanyak 20.127 orang. Laki-laki yang beristri tiga orang sebanyak 2.371 orang, dan lakilaki yang mempunyai istri empat terdapat sebanyak 455 orang. Dari jumlah tersebut, Sumatera Barat yang paling banyak berpoligami di antara kota-kota yang ada di Pulau Sumatera (Indisch Verslag, 1931)

\begin{tabular}{rrr}
\multicolumn{2}{c}{ Sedangkan menurut laporan } \\
Kolonial Belanda Indisch Verslag
\end{tabular} terbitan 1937, Sumatera Barat masih menduduki posisi poligami terbanyak di Pulau Sumatera. Terdapat sebanyak 338.636 laki-laki yangmenikah secara monogami. Sedangkan laki-laki yang berpoligami mempunyai istri dua sebanyak 29.742 orang. Selain itu, ada laki-laki yang mempunyai tiga orang istri sebanyak 3.127 orang, dan laki-laki yang beristri empat orang sebanyak 605 orang (Indisch Verslag, 1938).

Jika dibandingkan kedua catatan Kolonial Belanda di atas, terlihat angka laki-laki yang berpoligami di Sumatera Barat meningkat atau bertambah banyak. Tingginya angka poligami dalam masyarakat Minangkabau, menjadi perhatian oleh Pemerintah Kolonial Belanda. Pada tahun 1937, Pemerintah Kolonial Belanda mencanangkan untuk membuat ordonansi nikah bercatat atau Undang-Undang Perkawinan. Rancangan undang-undang itu nantinya akan mencatat setiap laki-laki yang menikah akan masuk kedalam catatan Kolonial Belanda dan itu hanya boleh seorang istri saja ("Gagasan dan aktiviti wartawan wanita Minangkabau pada masa kolonial Belanda,” 2012).

Dalam berbagai surat kabar dan majalah sudah diyakini, bahwa poligami di Minangabau berawal pada sikap orang Minangkabau yang materialistis. Orang tua mereka sangat senang apabila anak perempuannya menikah dengan seorang laki-laki yang kaya raya. Apabila anak perempuan tersebut sudah berumur 13 tahun, maka orang tua mereka mulai berfikir untuk mencarikan suami untuk anaknya. Dampaknya banyak para perempuan yang sudah menikah dalam umur yang masih sangat muda, yang mana masih dalam pertumbuhan. Pada masa itu perempuan memang belum 
HISTORIA: Jurnal Program Studi Pendidikan Sejarah Volume 8 (1) 2020

ISSN 2337-4713 (E-ISSN 2442-8728)

matang untuk membina hubungan rumah tangga. Seorang suami yang ingin dilayani bertolak belakang dengan seorang istri yang masih belum dewasa. Akibatnya terjadilah hubungan suami istri yang tidak harmonis akibat dari berbagai kesalahan seorang istri ("Gagasan dan aktiviti wartawan wanita Minangkabau pada masa kolonial Belanda," 2012).

Sebuah surat kabar bulanan persekutuan dari perkumpulanperkumpulan perempuan Asjraq menerbitkan salah satu tulisan yang menceritakan marahnya seorang suami terhadap istrinya yang melakukan kesalahan yang tidak begitu besar:

Sepoelang saja dari bekerdja saja lihat dia baroe hendak besedia, laloe diadjaknja saja makan. Sajapoen dengan peroet jang amat lapar, apalagi akan mendapat keinginan menoedjoe kemdja makan dengangirangnja. Apa jang terdjadi rendang jang diberikannja kepada saja, hitam seperti batoe baa, jang rasauja pahit poela,dan nasinja lembik berdetos, begitoelah oentoeng saja mendapat istri; dengan meradjoek saja tinggalkan dia sekarang, senang menangis sebabsaja marahi tengah ia makan. Demikianlah djadinja isteri saja itoe, nemanja sadja terpeladjar dan bagoes, tetapi pekerdjaannja begitoelah djadinja, mengesalkan hati saja. la berkata itoe dengan mengempaskan tangannja keatas medja (Moro, Fatimah, 1925).

Seorang suami yang marah besar terhadap istrinya hanya karena sang istri tidak bisa membuat rendang sesuai dengan keinginan suaminya. Lalu sang suami membentak dan marah kepada istrinya dan meninggalkan istrinya dalam kadaan sedang menangis. Kesalahan seorang istri mungkin saja terjadi karena umur serang istri yang masih terbilang remaja. Keadaan seperti itu bagi laki-laki dahulu sudah biasa dan kesempatan besar untuk mencari perempuan lain yang mereka sukai.("Gagasan dan aktiviti wartawan wanita Minangkabau pada masa kolonial Belanda," 2012)

Di Minangkabau kasus poligami sudah tidak asing lagi di dengar, bahkan di kalangan alim ulama di Minangkabau pun juga pernah terjadi. Dikalangan alim ulama praktek poligami pernah terjadi pada H. Abdul Karim Amrllah yang dikenal denganpanggilan Haji Rasul (ayah Hamka) juga melakukan poligami. Walaupun Haji Rasul adalah seorang ahli agama yang terkenal tapi ia juga belm dapat melepaskan diri dar ikatan masyarakat adatdinegerinya. Dalam buku Kenang-kenangan Hidup, Hamka mengisahkan bagaimana tiga orang orang istri ayahnya yang bergantian dibawa ke Padang Panjang dari puasa ke puasa lagi (Hamka, 1974). 
Perkawinan yang berulang-ulang, kawin dan cerai adalah suatu adat dan kemegahan yang harus dipegang teguh, baik orang yang terkemuka dalam adat, atau orang terkemuka dalam agama. Padi yang masih mencukupi untuk dimakan setahun, sawah yang berjenjang, ladang yang luas, merupakan sandaran teguh bagi seorang penghulu atau mamak akan menerima seorang-orang alim atau seorang penghulu jemputan menjadi manantu. Seperti halnya yang di alami oleh ayah Hamka (Hamka, 1974).

\section{Kasus-Kasus Poligami yang Pernah} Terjadi Di Minangkabau

Poligami merupakan permasalahan dalam perkawinan yang paling banyak diperdebatkan sekaligus kontroversial. Poligami banyak ditolak dengan berbagai argumentasi baik yang bersifat normatif. Psikologi bahkan selalu dikaitkan kedalam ketidak adilan gender. Para penulis barat sering mengklaim bahwa poligami adalah bukti bahwa ajaran Islam dalam bidang perkawinan sangat diskriminatif terhadap perempuan. Poligami disuarakan karena dianggap memiliki kesadaran normatif yang tegas dan dipandang sebagai salah satu alternatif untuk menyelesaikan fenomena selingkuh dan prostitusi (Arief Budiman, 2016).
Poligami memiliki akar sejarah yang panjang dalam perjalanan peradaban manusia itu sendiri. Sebelum Islam datang ke jazirah Arab, poligami merupakan sesuatu yang sudah mentradisi bagi masyarakat Arab. Poligami pada masa itu disebut dengan poligami tidak terbatas, bahkan lebih dari itu tidak ada gagasan yang nyata untuk keadilan bagi para istri-istri ketika itu. Suamilah yang menentukan ketika itu siapa yang disukai dan siapa yang dipilih untuk dimiliki secara tidak terbatas. Istri-istri harus menerima takdir mereka tanpa ada usaha memperoleh keadilan (Arief Budiman, 2016).

Di Minangkabau kasus poligami sudah tidak asing lagi di dengar, bahkan di kalangan alim ulama di Minangkabau pun juga pernah terjadi. Dikalangan alim ulama praktek poligami pernah terjadi pada H. Abdul Karim Amrullah yang dikenal dengan panggilan Haji Rasul (ayah Hamka) juga melakukan poligami. Walaupun Haji Rasul adalah seorang ahli agama yang terkenal tapi ia juga belum dapat melepaskan diri dari ikatan masyarakat adat di negerinya. Dalam buku Kenang-kenangan Hidup, Hamka mengisahkan bagaimana tiga orang orang istri ayahnya yang bergantian dibawa ke Padang Panjang dari puasa ke puasa lagi (Hamka, 1974)

Perkawinan yang berulang-ulang, kawin dan cerai adalah suatu adat dan 
HISTORIA: Jurnal Program Studi Pendidikan Sejarah Volume 8 (1) 2020

ISSN 2337-4713 (E-ISSN 2442-8728)

kemegahan yang harus dipegang teguh, baik orang yang terkemuka dalam adat, atau orang terkemuka dalam agama. Padi yang masih mencukupi untuk dimakan setahun, sawah yang berjenjang, ladang yang luas, merupakan sandaran teguh bagi seorang penghulu atau mamak akan menerima seorang-orang alim atau seorang penghulu jemputan menjadi manantu. Seperti halnya yang di alami oleh ayah Hamka (Hamka, 1974).

Selain ayah Hamka, poligami juga pernah dilakukan oleh Aziz Chan. la adalah seorang pahlawan nasional yang berasal dari Padang, Sumatera Barat. Istri pertama Aziz Chan bernama R.Ayu Entis Alisah yang dinikahinya pada tahun 1924. Sedangkan istri keduanya bernama Siti Zaura Usman, mereka menikah pada tanggal 28 Agustus 1946 (Muslim Ilyas, 1984).

Selain itu, kasus poligami juga dilakukan oleh seorang penulis Minangkabau yang berasal dari Payakumbuh, Sumatera Barat yaitu A. Damhoeri. Dalam kehidupan berumah tangga, Damhoeri pernah menikah sebanyak sembilan kali. Namun, dari kesembilan kali pernikahan itu tidak semuanya membawa kebahagiaan. Dari seringnya Damhoeri menikahitu, ia banyak mendapatkan inspirasi untuk menulis. Dari sejumlah pernikahan itu Damhoeri mempunyai anak sebanyak sembilan orang. Bakat menulis Damhoeri pun menurun pada anaknya, misalnya Nursjirwan Damhoeri. Di usianya yang telah senja, Damhoeri mempunyai cucu yang jumlahnya pun cukup banyak. la mengaku sangat senang bermain dengan cucu-cucunya itu (Atisah, 1995).

Poligami juga dilakukan oleh seorang ulama yang bernama Tuanku Mudo Alwi Koto Nan IV. Tuanku Alwi lahir pada tahun 1878 di Kubu Gadang, Koto Nan IV dan wafat pada tahun 1940. Dalam urusan rumah tangga, Tuanku Alwi Ibrahim seperti halnya ulamaulama Minangkabau seangkatannya juga sebagai ulama jemputan orang. Adat masa itu, ulama-ulama yang terpandang dirasa kurang baik bila beristri satu. Banyak masyarakat yang menjemput beliau untuk dijadikan mantu, berminantu kepada ulama terkemuka. Begitu pulalah Tuanku Alwi, ia mempunyai tiga orang istri selama hayatnya. Istri-istri beliau berasal dari daerah-daerah disekitar Koto Nan IV, yang satu berasal dari Balai nan Duo Koto Nan IV dan yang lainnya berasal dari Tanjung Pauh - Payakumbuh dan Balai Panjang (Apria Putra, 2011).

Selain itu ada juga ulama besar yng berpoligami seperti Syekh Abdul Wahid As-Shalihi yang lahir pada tahun 1878 dan wafat pada tahun 1950. Dalam hal berumah tangga, ia juga menjadi orang jemputan. Selama hayatnya, beliau mempunyai sebelas orang istri. Diantara istri-istri beliau itu ialah 
Raanah (Padang Kandih), Qamariyah (Koto Kecil), Maraya dan Fatimah (Ampang Gadang), Nuriyah, Mariah, Railah (ketiganya dari Padang Panjang), Jawa (Simalanggang), Marab (Tanjung Jati), Saniah (Tanjung Kaling-Sungai Kamuyang) dan Fatimah (Situjuh Bandar Dalam). Dari 11 istri beliau memperoleh anak 21 anak. Dari anak-anak beliau ini, hanya empat orang yang mengikuti jejaknya, yaitu H. Syarqawi Abdul Wahid, H. Anwar, Dumairi dan Suhaimi (Apria Putra, 2011).

\section{PENUTUP}

Simpulan

Di Minangkabau salah satu penyebab terjadinya poligami karena tekanan kaum reformis Islam terhadap adat tidak optimal (umumnya dipedesaan). Kaum reformis Islam menginginkan sistem matrilineal dihapus dan diganti seluruhnya dengan sistem yang sesuai dengan ajaran Islam. Ketidak senangan terhadap Belanda menjadi lahan subur bagi gerakan reformis Islam. Serangan terhadap adat di Minangkabau baru dimulai pada akhir abad ke-19. Sebelumnya pamor penghulu, bukan adat, sudah mulai menurun. Hal tersebut terjadi bukan karena ketidakmampuan mereka menjalankan tugas-tugas yang berkaitandengan adat, tapi karena dukungan terhadap tanam paksa, kerja paksa rosi, dan pajak yang menyebabkan keresahan. Otoritas penghulu menurun akibat terjadinya pengangkatan orangorang pilihan pemerintah kolonial sebagai penghulu, padahalmenurut adat mereka tidak mempunyai legitimasi.

Pada tahun 1908, setelah resminya dicabut sistem tanam paksa (Cultuurstelsel) karena gagal dan diganti dengan pajak uang, para penghulu yang tadinya berpihak kepada Belanda berubah haluan memimpin pemberontakan bersama para pedagang dan guru-guru tarikat. Tindakan ini dilakukan agar kembalinya kepercayaan masyarakat terhadap penghulu. Namun, pemberontakan tersebut menyebabkan penghulu semakin terpuruk, dipandang tidak sanggup memimpin, karena setiap pemberontakan berakhir dengan kegagalan. Alasan pemberontakan tersebut dilakukan adalah tekanan ekonomi dan ketidaksanggupan masyarakat memenuhi peraturan pemerintah. Tanam paksa yang gagal menyebabkan kemerosotan ekonomi, karena keharusan bekerja di kebunkebun kopi yang menyita tenaga dan waktu, sehingga hilangnya kesempatan masyarakat mengembangkan ekonimi mereka.

Dengan dihapuskannya sistem tanam paksa dan pemberlakuan sistem pajak uang, laki-laki berusaha sekuat tenaga untuk mendapatkan uang. Sistem ekonomi uang berkembang sangat pesat, sehingga melebarnya jurang status 
HISTORIA: Jurnal Program Studi Pendidikan Sejarah Volume 8 (1) 2020

ISSN 2337-4713 (E-ISSN 2442-8728)

ekonomi laki-laki dengan perempuan.

Laki-laki lebih menguasai peredaran uang karena mereka lebih dahulu masuk ke sistem tersebut dengan menjadi pedagang, tukang, buruh dan sebagainya. Sedangkan perempuan masih berada hanya di sektor pertanian dan mulai tidak terlindung oleh harta pusaka. Harta pusaka tidak bertambah karena mamak tidak lagi berusaha ke arah itu, sementara populasi kaum makin meningkat. Mamak lebih mencurahkan perhatian kepada anakanak mereka, terpengaruh oleh gerakan kaum muda dan perubahan pola pemukiman dari rumah gadang ke rumah-rumah berukuran kecil.

Saran

Penelitian mengenai Poligami di Minangkabau pada Masa Kolonial menarik dilakukan karena poligami dan ordonansi yang dikeluarkan Pemerintah Hindia Belanda telah membawa serangkaian dampak terhadap kehidupan sosial di dalam keluarga terutama di dalam kehidupan sosial perempuan. Bahkan memungkinkan untuk mengadakan penelitian lebih lanjut, bagaimanakah keadaan masyarakat Minangkabau setelah terjadinya serangkaian peristiwa saat poligami di Minangkabau terjadi pada masa kolonial dan apakah ada pergerakan perempuan Minangkabau setelah itu.

\section{Daftar Pustaka}

Amerady Chatra. (2005). Orang Jemputan Regulasi Seksualitas dan Poligami di Minangkabau. Laboratorium Sosiologi FISIP Unand.

Antuli, S. A. (2016). Poligami Dan Permasalahannya Kandungan Hukum QS. An-Nisa' (4): 3 \& 29. Jurnal Ilmiah Al-Syir'ah. https: //doi.org/10.30984/as.v6i2. 250

Apria Putra. (2011). Ulama-ulama Luak Nan Bungsu: Catatan Biografi Ulama-ulama Luak Limopuluah Kota Serta Perjuangannya. Minangkabau Press.

Arief Budiman. (2016). Analisis Yuridis Terhadap Kawin Batambuah Yang Dilakukan Oleh Masyarakat Adat Minangkabau Agam Sumatera Barat. Universitas Sumatera Utara.

Atisah. (1995). Biografi A. Damhoeri dan Karyanya. Pusat Pembinaan dan Pengembangan Bahasa.

Clark, E. A., \& Gottschalk, L. (1951). Understanding History: A Primer of Historical Method. The Hispanic American Historical Review. https: / /doi.org/10.2307/2509437

Darmawijaya, E. (2015). Poligami Dalam Hukum Islam Dan Hukum Positif (Tinjauan Hukum Keluarga Turki, Tunisia dan Indonesia). Gender Equality: Internasional Journal of Child and Gender Studies.

Gagasan dan aktiviti wartawan wanita Minangkabau pada masa kolonial Belanda. (2012). JEBAT : Malaysian Journal of History, Politics and Strategic Studies.

Hadler, J. (2010). Sengketa Tiada Putus: Matriakat, Reformisme Islam, dan Kolonialisme di Minangkabau. In Freedom Institute. 
Hamka. (1974). Kenang-Kenangan Hidup. Bulan Bintang.

Indisch Verslag. (1938). Monogamie En Polygamie $\mathrm{Bij}$ Inlanders En Vreemde Oosterlingen. Landsdrukkerij.

Moro, Fatimah, R. (1925, April). Perempoean Dengan Roemah Tangganja. Asjraq.

Muhammad Radjab. (1969). Sistem Kekerabatan Di Minangkabau. Center For Minangkabau Studies Press.

Muslim Ilyas. (1984). Riwayat dan Perjuangan Aziz Chan. PT. Telaga Gunung.

Putri, S. M. (2018). Perempuan dan Modernitas. Gre Publishing.

Untung Yuwono. (2008). Ketika Perempuan Lantang Menentang Poligami. Jurnal Wacana.

Yoce Aliah Darma. (2009). Analisis Wacana Kritis. Yrama Widya. 